Original articles

J. Perinat. Med. 13 (1985) 219

\section{Amniotic fluid thyrotropin (TSH) following maternal administration of thyrotropin releasing hormone*}

\author{
G. Robuschi, L. E. Braverman***, R. Emanuele, L. d'Amato, E. Gardini, \\ M. S. Foscolo**, C. Gualerzi**, L. Benassi, A. Gnudi, E. Roti
}

Cattedra di Endocrinologia e Patologia Costituzionale, Clinica Ostetrica e Ginecologica, University of Parma Medical School, Parma and **Divisione di Ostetricia e Ginecologia, Ospedale E. Franchini, Montecchio Emilia, Italy, and ${ }^{* * *}$ Division of Endocrinology and Metabolism, University of Massachusetts Medical School, Worcester, U.S.A.

\section{Introduction}

Early treatment of hypothyroid neonates is essential to prevent mental retardation. This goal can be achieved by neonatal hypothyroidism screening which has proved to be a rapid and effective method to detect hypothyroid newborns [3]. In pregnancies at risk for the presence of fetal hypothyroidism, such as hyperthyroid mothers accidentally treated with ${ }^{131} \mathrm{I}$ after 10 weeks of pregnancy or treated with antithyroid drugs, it seems reasonable to make an in utero diagnosis of fetal hypothyroidism. Medical treatment of the hypothyroid fetus by the administration of thyroxine $\left(\mathrm{T}_{4}\right)$ into the amniotic cavity or intramuscularly may be effective $[17,28]$ although cord blood $(\mathrm{CB}) \mathrm{T}_{4}$ and $\mathrm{T}_{3}$ concentrations were undetectable and TSH concentration was elevated in the fetus treated intramuscularly [17]. The diagnosis of intrauterine hypothyroidism has been attempted by measurement of $T_{4}$ or $\mathrm{PBI}$ in amniotic fluid (AF) resulting in values apparently reflecting thyroid function in the

\footnotetext{
* This work was supported by Grant n. 82.00201 .04 of Consiglio Nazionale delle Ricerche, Roma, and Grant AM 18919, NIAMDD, NIH, Bethesda, MD.
}

\section{Curriculum vitae}

Dr. Elio Roti is an established Investigator in Endocrinology at the University of Parma Medical School, Parma, Italy. He was a NATO Fellow in Endocrinology at the University of Massachusetts $\mathrm{Me}$ dical School, Worcester, Massachusetts, where his main research interest was concerned with the metabo-

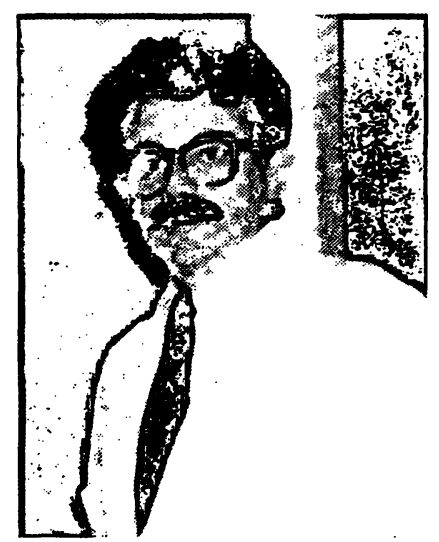
lism of the thyroid hormones by the placenta and fetal membranes. He has continued his research on various aspects of the control of thyroid and pituitary function during the perinatal period.

neonate [10]. However, the concentrations of $\mathrm{T}_{4}$ and triiodothyronine $\left(\mathrm{T}_{3}\right)$ in unconcentrated AF are low or undetectable and, therefore, these tests may not be clinically useful in detecting fetal hypothyroidism [4, 26]. Measurement of $A F$ reverse $T_{3}\left(r T_{3}\right)$ has been proposed as a useful method to detect fetal hypothyroidism [4]. However, low AF $\mathrm{rT}_{3}$ was not useful in detecting a few patients with proven fetal hypothyroidism [16]. 
More recently it has been suggested that measurement of AF thyrotropin (TSH) could be a reliable test to diagnose primary fetal hypothyroidism [27], although this is somewhat controversial [21]. In support of this possibility, KoURIDES et al. have reported that TSH can be detected in 3 to 8 fold concentrates of AF and have suggested that an elevation of AF TSH may be useful in the diagnosis of primary fetal hypothyroidism [13]. The present study was undertaken to determine whether fetal hyperthyrotropinemia, induced by the administration of thyrotropin releasing hormone (TRH) to the mothers during labor [23], would result in an increase in AF TSH concentrations obtained during labor and delivery.

\section{Material and methods}

After informed consent was obtained by the obstetrician prior to labor, 65 women with uncomplicated pregnancies were studied at term. Sixteen received an iv injection of $2 \mathrm{ml}$ of saline and the others, selected at random, were treated with $400 \mu \mathrm{g}$ synthetic TRH iv (Biodata, Milan, Italy). After the umbilical cord was cut, CB was obtained from the placental side of the cord which represents fetal blood and is a mixture of arterial and venous blood. Samples of amniotic fluid were obtained in one of 2 ways. In the 31 women who were delivered by Caesarian section, amniocentesis was performed through the fetal membranes after uterine incision. Amniorexis is a common practice during labor in these obstetrical units. Therefore, in the 34 women who were delivered vaginally, amniocentesis was carried out under direct visualization through the fetal sac after it protruded through the dilated cervical os. In some women, vaginal amniocentesis was carried out on 2 occasions. In both groups of women, AF was obtained only if a sufficient volume of AF was interposed between the fetus and fetal membranes. All amniocenteses were carried through a $140 \mathrm{~mm}, 0.7 \mathrm{~mm}$ gauge needle. No adverse effects were observed during labor and delivery or during the neonatal period following TRH administration. The times of TRH injection, CB and AF sampling were recorded. AF specimens contaminated with blood or meconium were not included. Only AF which was clear by visual inspection was evaluated. Portions of all the AF specimens were concentrated 4 fold by lyophilization and then reconstituted in $0.01 \mathrm{M} \mathrm{Na} \mathrm{PO}_{4}, \mathrm{pH} 7.4$, $0.25 \%$ bovine serum albumin buffer. Serum and AF specimens were kept frozen at $-20^{\circ} \mathrm{C}$ until analysis. Except for a few specimens, TSH, $\mathrm{T}_{4}, \mathrm{~T}_{3}$ and $\mathrm{rT}_{3}$ were measured in all $\mathrm{CB}$ and unconcentrated AF samples. TSH was also measured in the concentrated AF samples.

Hormone analyses: TSH was measured by RIA using materials obtained from the National Pituitary Agency, NIAMDD (Bethesda, MD); $300 \mu l$ of serum or AF or buffer were employed in the TSH assay. The protein content in clear, concentrated AF was approximately $250 \mathrm{mg} /$ $\mathrm{dl}, 92$ percent of which is albumin. The diluent for the standard curve used in the measurement of AF TSH consisted of phosphate buffer, $0.01 \mathrm{M}, \mathrm{pH} 7.4$, enriched with human serum albumin (HSA) to approximate the concentration of protein in AF. This concentration of HSA did not affect the standard curve. The recovery of human TSH added to AF is 100 percent. The lowest detectable TSH concentration was $0.2 \mu \mathrm{U} /$ tube corresponding to $0.6 \mu \mathrm{U} / \mathrm{ml}$. $\mathrm{T}_{4}$ was measured in serum and $\mathrm{AF}$ by RIA using material supplied by Biodata. Serum and $A F T_{3}$ and $\mathrm{rT}_{3}$ were measured by methods previously described $[1,19]$. Sensitivity of the assays for the thyroid hormones are: $\mathrm{T}_{4}$, $0.6 \mu \mathrm{g} / \mathrm{dl} ; \mathrm{T}_{3}, 6.2 \mathrm{ng} / \mathrm{dl} ; \mathrm{rT}_{3}, 2.5 \mathrm{ng} / \mathrm{dl}$.

All samples were assayed for each hormone in duplicate, in the same assay and in random order.

Data analysis: Hormone values in $\mathrm{CB}$ and $\mathrm{AF}$ samples from mothers treated with saline were assigned to one group (group 0). Hormone concentrations in $\mathrm{CB}$ and $\mathrm{AF}$ specimens from women treated with TRH were assigned to different groups (1 to 5) depending upon the duration of time between TRH administration and $\mathrm{CB}$ and AF samples. There was no significant difference in gestational age or birth weight among the various groups. 
Statistical analysis was carried out by one way analysis of variance (ANOvA, F test) and Duncan's multiple range test corrected for an unequal number of determinations [14] to compare the value of group 0 (saline treated) and groups 1 to 5 (TRH treated). All results are reported as the mean $\pm S E$.

\section{Results}

TSH concentrations in $\mathrm{CB}$ and in unconcentrated $\mathrm{AF}$ are shown in Fig. 1. In group 0 , CB TSH was $5.0 \pm 0.3 \mu \mathrm{U} / \mathrm{ml}$. A significant variation in $\mathrm{CB}$ TSH concentration was observed in groups whose mothers received TRH ( $<<0.01, F$ test). A peak value of $38.0 \pm 4.2 \mu \mathrm{U} / \mathrm{ml}$ was observed in group 2 , sampled from 61 to $120 \mathrm{~min}$ after TRH. This value was highly significant vs values obtained in group $0(p<0.01$, Duncan's test). A significant increase in TSH, as compared to group
0 , was observed in groups 1 and 3 (p $<0.01$, Duncan's test) and also in group 4 sampled from 181 to $240 \mathrm{~min}$ after TRH $(p<0.05$, Duncan's test).

TSH was below the limit of detectability in unconcentrated AF samples obtained from all groups. TSH was also undetectable in AF samples concentrated 4 fold except for two specimens sampled at 75 and $140 \mathrm{~min}$ after TRH administration $(1.3$ and $1.0 \mu \mathrm{U} / \mathrm{ml}$, respectively) and in three samples in group 0 with values of $1.0 \mu \mathrm{U} / \mathrm{ml}$. In $A F$ specimens contaminated with blood, not included in these groups, TSH concentrations as high as $2.3 \mu \mathrm{U} /$ $\mathrm{ml}$ were observed.

The concentrations of $T_{4}, T_{3}$ and $\mathrm{rT}_{3}$ in cord blood confirmed our earlier findings (23) (Tab. I). In group 0 , the mean $T_{4}$ concentration was $10.9 \pm 0.5 \mu \mathrm{g} / \mathrm{dl}$. In groups 1 to 5 , a significant increase was observed $\mathrm{p}<0.01$ ( $\mathrm{F}$ test) with a peak value of $14.7 \pm 0.9 \mu \mathrm{g} / \mathrm{dl}$ in group 4

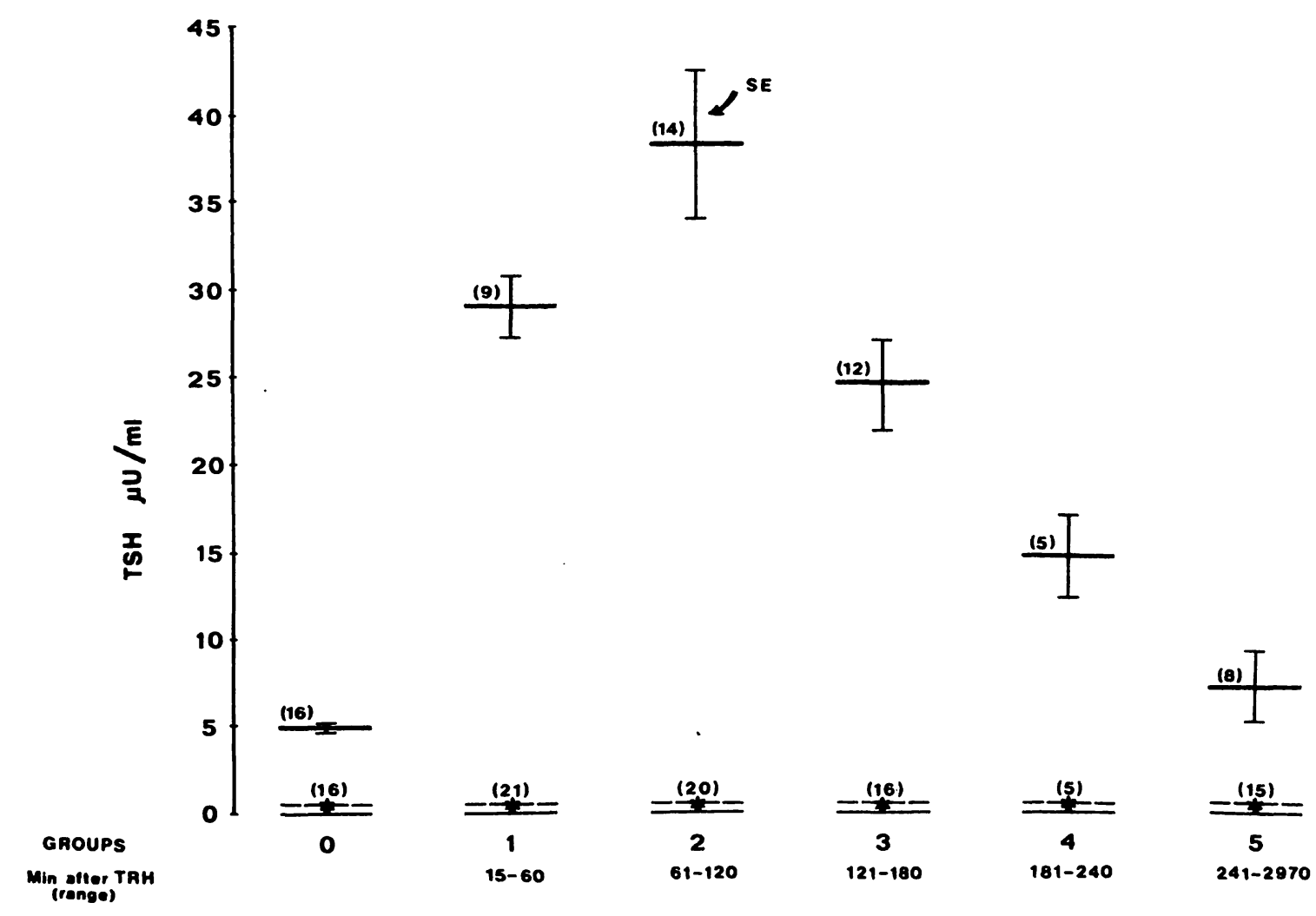

Fig. 1. TSH concentration in CB (-) and in non concentrated AF samples $\left(^{*}\right)$ of group 0 (control) and groups 1 to 5 (TRH treated) sampled at different time intervals after maternal TRH administration. The values are reported as the mean $\pm \mathrm{SE}$. The number of observations for each group is noted in the parentheses. The dotted line represents the limit of detectability of the TSH assay $(0.6 \mu \mathrm{U} / \mathrm{ml})$. 
sampled 181 to $240 \mathrm{~min}$ after $\mathrm{TRH}$ administration. $T_{3}$ concentration was $43.4 \pm$ $3.7 \mathrm{ng} / \mathrm{dl}$ in group 0 and a significant increase was observed in groups 1 to $5, \mathrm{p}<0.01$ (F test), reaching a peak value of $107.3 \pm 5.6 \mathrm{ng} /$ dl in group 3, sampled 121 to $180 \mathrm{~min}$ after TRH administration. CB $\mathrm{rT}_{3}$ concentration was similar in control and TRH treated mothers. The concentrations of iodothyronines in unconcentrated AF are reported in Tab. II. $\mathrm{T}_{4}$

Tab. I. $\mathrm{T}_{4}, \mathrm{~T}_{3}$ and $\mathrm{rT}_{3}$ concentrations in cord blood (CB) from control (group 0) and TRH treated women (groups 1 to 5$)$.

\begin{tabular}{lcccccccc}
\hline Groups & 0 & 1 & 2 & 3 & 4 & 5 & & \\
& & $15-60^{\mathrm{a}}$ & $61-120$ & $121-180$ & $181-240$ & $241-2970$ & & \\
& & $38.3 \pm 2.8^{\mathrm{b}}$ & $86.9 \pm 8.5$ & $156.8 \pm 4.3$ & $220.9 \pm 7.8$ & $1026.5 \pm 313.5$ & & \\
\hline $\mathrm{T}_{4}$ & $10.9^{\mathrm{c}}$ & 12.0 & 12.3 & 13.5 & 14.7 & 12.5 & F test $^{\mathrm{f}}$ & $\mathrm{p}<0.01$ \\
$(\mu \mathrm{g} / \mathrm{dl})$ & $0.5^{\mathrm{d}}$ & 0.7 & 0.7 & 0.6 & 0.9 & 0.7 & & \\
& $16^{\mathrm{e}}$ & 8 & 9 & 10 & 6 & 7 & & \\
$\mathrm{~T}_{3}$ & 43.4 & 67.6 & 94.2 & 107.3 & 73.9 & 49.1 & $\mathrm{~F}$ test & $\mathrm{p}<0.01$ \\
$(\mathrm{ng} / \mathrm{dl})$ & 3.7 & 9.6 & 4.5 & 5.6 & 8.2 & 7.2 & & \\
& 16 & 9 & 14 & 12 & 6 & 8 & & \\
$\mathrm{rT}$ & 242.5 & 256.9 & 257.9 & 248.4 & 282.1 & 251.9 & F test & NS \\
$(\mathrm{ng} / \mathrm{dl})$ & 13.9 & 11.9 & 17.4 & 14.6 & 20.5 & 11.4 & & \\
& 16 & 9 & 12 & 12 & 6 & 8 & & \\
\hline
\end{tabular}

a The range of time (minutes) between maternal TRH administration and CB samples

b The mean \pm SE of time (minutes) between maternal TRH administration and CB samples

c The mean of values for each hormone

d $\pm \mathrm{SE}$

e Number of observations

f ANOVA test including all groups

Tab. II. $\mathrm{T}_{4}, \mathrm{~T}_{3}$ and $\mathrm{r} \mathrm{T}_{3}$ concentrations in unconcentrated amniotic fluid (AF) samples of control ( 0 group) and TRH treated women (groups 1 to 5).

\begin{tabular}{|c|c|c|c|c|c|c|c|c|}
\hline Groups & 0 & $\begin{array}{l}1 \\
0-60^{\mathrm{a}} \\
39 \pm 3.3^{\mathrm{b}}\end{array}$ & $\begin{array}{l}2 \\
61-120 \\
90.9 \pm 4.5\end{array}$ & $\begin{array}{l}3 \\
121-180 \\
160.7 \pm 3.7\end{array}$ & $\begin{array}{l}4 \\
181-240 \\
207 \pm 9.8\end{array}$ & $\begin{array}{l}5 \\
241-2970 \\
813.6 \pm 86.7\end{array}$ & & \\
\hline $\begin{array}{l}\mathrm{T}_{4} \\
(\mu \mathrm{g} / \mathrm{dl})\end{array}$ & $\begin{array}{l}1.3^{\mathrm{c}} \\
0.1^{\mathrm{d}} \\
16^{\mathrm{e}}\end{array}$ & $\begin{array}{l}1.3 \\
0.4 \\
20\end{array}$ & $\begin{array}{l}1.2 \\
0.1 \\
19\end{array}$ & $\begin{array}{l}1.1 \\
0.1 \\
16\end{array}$ & $\begin{array}{l}1.0 \\
0.2 \\
5\end{array}$ & $\begin{array}{l}0.8 \\
0.1 \\
13\end{array}$ & $F$ test $^{\mathrm{f}}$ & NS \\
\hline $\begin{array}{l}\mathrm{T}_{3} \\
\text { (ng/dl) }\end{array}$ & $\begin{array}{c}<6.25 \\
0 \\
16\end{array}$ & $\begin{array}{c}<6.25 \\
0 \\
21\end{array}$ & $\begin{array}{c}<6.25 \\
0 \\
19\end{array}$ & $\begin{array}{c}<6.25 \\
0 \\
15\end{array}$ & $\begin{array}{c}<6.25 \\
0 \\
5\end{array}$ & $\begin{array}{c}<6.25 \\
0 \\
15\end{array}$ & $F$ test & NS \\
\hline $\begin{array}{l}\mathrm{rT}_{3} \\
\text { (ng/dl) }\end{array}$ & $\begin{array}{c}55.6 \\
9.5 \\
15\end{array}$ & $\begin{array}{r}46.4 \\
5.9 \\
21\end{array}$ & $\begin{array}{c}51.5 \\
6.6 \\
20\end{array}$ & $\begin{array}{c}54.4 \\
5.4 \\
16\end{array}$ & $\begin{array}{c}55.2 \\
9.6 \\
5\end{array}$ & $\begin{array}{c}52.6 \\
9.2 \\
15\end{array}$ & $F$ test & NS \\
\hline
\end{tabular}

a The range of time (minutes) between maternal TRH administration and AF samples

b The mean \pm SE of time (minutes) between maternal TRH administration and CB samples

c The mean of values for each hormone

d $\pm \mathrm{SE}$

e Number of observations

f ANOVA test including all groups 
concentration in AF in all groups was barely detectable and no variation was observed. $T_{3}$ was not detectable in any of the samples. $\mathrm{rT}_{3}$ concentrations in group 0 and in groups 1 to 5 ranged between 46.4 and $55.6 \mathrm{ng} / \mathrm{dl}$ and did not differ between groups.

\section{Discussion}

Neonatal thyroid screening has provided a useful tool for the detection of hypothyroid newborns resulting in early treatment of these infants, thus avoiding permanent mental retardation due to thyroid hormone deficiency during the neonatal period. However, possible approaches to the intrauterine diagnosis of fetal hypothyroidism have been suggested [27]. Measurement of $\mathrm{rT}_{3}$ in $\mathrm{AF}$ was proposed as a possible approach to evaluate fetal thyroid function [9]. However, later studies have indicated that this test was not useful in diagnosing fetal hypothyroidism [16]. In the rat, it has been demonstrated that $\mathrm{AF} \mathrm{rT}_{3}$ is more dependent upon maternal thyroid function than fetal thyroid status [6] and it has been postulated that fetal $\mathrm{rT}_{3}$ arises, at least in part, from the inner ring deiodination of $\mathrm{T}_{4}$ by placenta and fetal membranes [22, 24, 25].

Recently, Kourides et al. [13] have detected TSH in 3 to 8 fold concentrates of AF suggesting the possibility of diagnosing primary fetal hypothyroidism. In a previous study we were able to detect TSH in only a few specimens of AF [20]. In the present report, TSH was not detectable in the unconcentrated AF samples. After a 4 fold concentration, TSH was still undetectable in almost all AF samples obtained in saline and TRH treated women at term. These conflicting results are probably due to the different sensitivities of the two TSH assays, $0.15 \mu \mathrm{U} / \mathrm{ml}$ [10] vs $0.6 \mu \mathrm{U} / \mathrm{ml}$ (present study). The aim of the present study, however, was to evaluate whether a marked increase in fetal serum TSH would result in a corresponding elevation in AF TSH. After the administration of TRH to the term pregnant woman, CB TSH concentrations were markedly increased, reaching values as high as $63.3 \mu \mathrm{U} / \mathrm{ml}$. This increase in CB TSH did not result in a detectable increase in AF TSH even when the AF was concentrated 4 fold. In the adult, TSH has a biological half life of 50-60 minutes and is mainly metabolized by the kidney. Moreover, immunoreactive TSH is not found in the urine [5]. In the newborn, the half life of endogenous TSH is 77 minutes [8]. It is not known how fetal TSH reaches the amniotic fluid. Possible sources of AF TSH include fetal urinary excretion, if the fetal kidney excretes intact TSH, which seems unlikely in view of the data noted above in the adult and newborn, or passage through the pars placentaris of the amnion from the chorion plate and placenta. It is possible, however, that the fetal kidney in mid gestation might not degrade the elevated serum TSH present in hypothyroidism which could result in urinary excretion of and a subsequent elevation in amniotic fluid TSH. Degradation of fetal TSH by AF does not seem likely. Previous studies have demonstrated that a small peptide like TRH is not degraded by AF in vitro [18] and other protein hormones, such as prolactin and growth hormone, are readily detectable in AF [2].

In a previous study, AF TSH measured before $\mathrm{T}_{4}$ injection into the amniotic cavity was undetectable in suspected fetal hypothyroidism due to maternal treatment with ${ }^{131} \mathrm{I}$ at $10-11$ weeks of pregnancy [17]. In other cases of proven fetal hypothyroidism, AF TSH unfortunately was not measured [16, 7]. HOLLINGSWORTH et al. have reported high concentrations of AF TSH in the sheep following fetal hypothyroidism induced by intrauterine thyroidectomy [11]. The presence of high concentrations of TSH in AF may be due to the different placental structure in the sheep compared to man. The ovine placenta consists of separate cotyledons whereas the human placenta is a single mass. Furthermore, although unlikely, serum TSH could have reached the AF through the surgical thyroidectomy scar. In the present study, AF TSH was elevated in saline and TRH treated women when the AF samples were contaminated with blood. 
Although elevations of fetal serum TSH concentrations for as long as 4 hours did not result in elevated AF TSH concentrations in the present study, it should be emphasized that fetal hypothyroidism is most often due to thyroid agenesis or dysgenesis [15] which would result in a more prolonged and greater elevation of fetal serum TSH. Whether the longer duration of an even higher elevation of fetal serum TSH concentrations would result in an increase in AF TSH remains conjectural. It should also be emphasized that the present study was carried out in the term fetus and it is possible that elevations in serum $\mathrm{TSH}$ in mid gestation might result in an increase in TSH content in the amniotic fluid at that time. However, since this study was completed, HollingSWORTH and ALEXANDER reported that measurements of AF concentrations of thyroid hormones and TSH do not reliably predict fetal or neonatal thyroid status [12].

\section{Summary}

Cord blood and amniotic fluid thyrotropin (TSH), $\mathrm{T}_{4}$, $\mathrm{T}_{3}$, and $\mathrm{rT}_{3}$ concentrations were measured in 49 women who received $400 \mu \mathrm{g}$ thyrotropin releasing hormone (TRH) iv during labor and in 16 control women who received saline. Cord blood serum TSH concentrations were elevated for as long as 4 hours after TRH administration and peak values $(38.0 \pm 4.2 \mu \mathrm{U} / \mathrm{ml})$ were observed from $61-120$ minutes after TSH as compared to control values of $5.0 \pm 0.3 \mu \mathrm{U} / \mathrm{ml}$. The elevations in fetal TSH concentration stimulated the fetal thyroid, resulting in a progressive increase in cord blood $\mathrm{T}_{4}$ and $\mathrm{T}_{3}$ but not $\mathrm{rT}_{3}$ concentrations. These TRH induced elevations in fetal cord blood TSH concentrations were not accompanied by increases in unconcentrated and 4 fold concentrated amniotic fluid TSH concentrations which were almost always below $0.6 \mu \mathrm{U} / \mathrm{ml}$, the limit of assay sensitivity. Unconcentrated amniotic fluid $\mathrm{T}_{4}$

concentrations were barely detectable and no variation was observed between the TRH treated and saline treated mothers; amniotic fluid $T_{3}$ was not detectable in any of the groups; and amniotic fluid $\mathrm{rT}_{3}$ concentrations ranged between 46.4 and $55.6 \mathrm{ng} / \mathrm{dl}$ and did not differ between groups.

These findings suggest that term amniotic fluid TSH values do not reflect transient but marked elevations in fetal serum TSH concentrations and that amniotic fluid TSH determination is probably not useful in the detection of primary fetal hypothyroidism. It is possible, but unlikely, that long-term and even greater elevations in fetal serum TSH concentrations would result in increased amniotic fluid TSH concentrations. Thus, there appears to be little use in measuring amniotic fluid TSH concentrations for diagnosing fetal hypothyroidism.

Keywords: Amniotic fluid, thyrotropin, thyrotropin releasing hormone.

\section{Zusammenfassung}

TSH im Fruchtwasser nach Gabe von TRH an die Mutter In 49 Fällen, in denen die Mutter unter der Geburt $400 \mu \mathrm{g}$ TRH erhalten hatte, wurden im Nabelblut und im Fruchtwasser die Konzentrationen von $\mathrm{TSH}_{1} \mathrm{~T}_{4}, \mathrm{~T}_{3}$ und $\mathrm{rT}_{3}$ bestimmt. Die Kontrollgruppe mit 16 Frauen erhielt $\mathrm{NaCl}$. Die TSH-Konzentration im Nabelblut war bis $\mathrm{zu} 4 \mathrm{~h}$ nach der TRH-Gabe erhöht. Peaks (38.0 \pm $4.2 \mu \mathrm{U} / \mathrm{ml}$ ) zeigten sich zwischen 61-120 min nach TRH-Gabe; in der Kontrollgruppe lagen die Peaks bei $5.0 \pm 0.3 \mu \mathrm{U} / \mathrm{ml}$. Die erhöhte fetale TSH-Konzentration führte über die Stimulation der Schilddrüse zu einem steilen Anstieg von $\mathrm{T}_{3}$ und $\mathrm{T}_{4}$, nicht aber $\mathrm{rT}_{3}$ im Nabelblut. Dagegen waren die TSH-Werte sowohl in nichtkonzentriertem wie auch in vierfach konzentriertem Fruchtwasser nicht erhöht; sie lagen immer unter der Nachweisgrenze von $0.6 \mu \mathrm{U} / \mathrm{ml}$. $\mathrm{T}_{4}$ war im Fruchtwasser kaum nachwèisbar; es zeigte sich kein Unterschied zwischen der behandelten Gruppe und der Kontrollgruppe. $T_{3}$ war im Fruchtwasser überhaupt nicht nachweisbar. Die $\mathrm{rT}_{3}$-Konzentration variierte sowohl in der unbehandelten wie auch in der behandelten Gruppe zwischen 46.4 und $55.6 \mathrm{ng} / \mathrm{dl}$.

Unsere Ergebnisse zeigen, daß die TSH-Werte im Fruchtwasser am Termin deutliche, wenn auch vorübergehende Anstiege der fetalen TSH-Werte im Serum nicht widerspiegeln. Die TSH-Bestimmung im Fruchtwasser scheint damit für die Aufdeckung einer primären fetalen Hypothyreose ungeeignet. Möglicherweise könnten länger anhaltende und auch stärkere Anstiege der TSHKonzentration im fetalen Serum erhöhte TSH-Werte im Fruchtwasser bewirken. Uns erscheint jedoch die Messung von TSH im Fruchtwasser für die Diagnose einer fetalen Hypothyreose wenig brauchbar. 


\section{Résumé}

Thyréotropine (T. S. H.) dans le liquide amniotique après administration maternelle de thyréotropine releasing hormone

On a mesuré chez 49 femmes ayant reçu 400 microgrammes de thyréotropine releasing hormone en I. V. au cours du travail, ainsi que chez 16 femmes contrôlées ayant reçu un serum salé, les concentrations de thyréotropine (T. S. H.) de T4, de T3 et de $\mathrm{r}$ T3 au sang du cordon et dans le liquide amniotique.

Les concentrations de T. S. H. au sang du cordon sont élevées pendant les 4 heures suivant l'injection de T. R. H. et les valeurs du pic $(38,0+$ ou $-4,2$ micro $U /$ $\mathrm{ml}$ ) sont observées de 61 à 120 minutes après T. S. H. en comparaison avec les valeurs des témoins qui sont de $5,0+$ ou $-0,3$ micro $\mathrm{U} / \mathrm{ml}$.

L'élévation de la concentration fœtale de T. S. H. stimule la thyroïde fœtale, ce qui entraîne une augmentation progressive des concentrations au sang du cordon de T4 et de T3, mais pas de rT3. Cette élévation des concentrations de T.S. H. au sang du cordon induite par la T. R. H. ne s'est pas accompagnée d'une augmentation des concentrations de T.S.H. dans le liquide amniotique, celles-ci restant presque toujours inférieures à $0,6 \mathrm{micro} \mathrm{U} / \mathrm{ml}$, ce qui est la limite de sensibilité du dosage.

Les concentrations de $\mathrm{T} 4$ dans le liquide amniotique non concentré étaient à peine détectables et l'on n'a pas observé de variation entre les mères traitées par T. R. H. et celles traitées par du serum salé; la T3 amniotique n'était pas détectable dans les deux groupes et les concentrations de $\mathrm{r}$ T3 dans le liquide amniotique étaient comprises entre 46,4 et $55,6 \mathrm{ng} / \mathrm{dl}$ et n'étaient pas différentes dans les deux groupes.

Ces résultats suggèrent que les valeurs de la $\mathrm{T}$. S. H. dans le liquide amniotique à terme ne reflètent pas une élévation transitoire mais marquée des concentrations de T. S. H. sérique fœtale et que la mesure de la T. S. H. dans le liquide amniotique n'est probablement pas utile pour détecter une hypothyrö̈die fetale primaire. Il est possible mais peu probable que les élévations à long terme, même les plus importantes, des concentrations de la T.S. H. sérique fœtale pourraient entrainer une augmentation des concentrations de la T.S. H. dans le liquide amniotique. Ainsi, il apparaît qu'il est de peu d'utilité de mesurer les concentrations de T. S. H. dans le liquide amniotique pour le diagnostic de l'hypothyroïdie fœtale.

Mots-clés: Liquide amniotique, thyréotropine, thyréotropine releasing hormone.

\section{Bibliography}

[1] Bandini, P., G. Robuschi, R. Emanuele, A. GNUDI, E. Rotr: Dossaggio radioimmunologico della triiodotironina $\left(\mathrm{T}_{3}\right)$ nel siero. Lab. J. Res. Med. 6 (1979) 495

[2] Belisle, S., D. Tulchinsky: Amniotic fluid hormones. In: TULCHINSKY, D., K. Y. RYAN (eds.): Maternal-fetal endocrinology. W. B. Saunders Company, Philadelphia 1980, p. 169

[3] Burrow, G. N., J. H. Dussault: Neonatal thyroid screening. Raven Press, New York 1980

[4] Chopra, I. J., B. F. CRandall: Thyroid hormones and thyrotropin in amniotic fluid. N. Engl. J. Med. 293 (1975) 740

[5] Cuttelod, S., T. Lemarchand-Beraud, P. Magnenat, C. Perret, S. Poli, A. Vannotti: Effect of age and role of kidneys and liver on thyrotropin turnover in man. Metabolism 23 (1974) 101

[6] El-ZAHeri, M.M., A. G. VAGenakis, L. Hinerfeld, C. H. EMERSON, L. E. BRAVERMAN: Maternal thyroid function is the major determinant of amniotic fluid $3,3^{\prime} 5^{\prime}$-triiodothyronine in the rat. J. Clin. Invest. 67 (1981) 1126

[7] Filetti, S., M. Camus, F. Rodesch, F. Delange, R. Vigneri, A. M. ERmans: Decreased reverse triiodothyronine $\left(\mathrm{rT}_{3}\right)$ concentration in amniotic fluid in fetal hypothyroidism. Arch. Dis. Child. 52 (1977) 430
[8] Fisher, D. A., W. D. Odell: Acute release of thyrotropin in the newborn. J. Clin. Invest. 48 (1969) 1670

[9] FISHER, D. A.: Reverse tri-iodothyronine and fetal thyroid status. N. Engl. J. Med. 293 (1975) 770

[10] Hollingsworth, D. R., E. Austin: Thyroxine derivatives in amniotic fluid. Fetal outcome in three patients with thyroid problems. J. Pediatr. 79 (1971) 923

[11] Hollingsworth, D. R., S. L. Davis, I. J. Chopra, R. P. BELIN, M. C. REID: Antenatal diagnosis of cretin lambs by measurement of amniotic fluid thyrotropin. Proc. Soc. Exp. Biol. Med. 157 (1978) 106

[12] Hollingsworth, D. R., N. M. Alexander: Amniotic fluid concentrations of iodothyronines and thyrotropin do not reliably predict fetal thyroid status in pregnancies complicated by maternal thyroid disorders or anencephaly. J. Clin. Endocrinol. Metab. 57 (1983) 349

[13] Kourides, I. A., C. V. Heath, F. GinsbergFELLNER: Measurement of thyroid-stimulating hormone in human amniotic fluid. J. Clin. Endocrinol. Metab. 54 (1982) 635

[14] KRAMER, C. Y.: Extension of multiple range tests to group means with unequal number of replications. Biometrics 12 (1956) 307 
[15] La Franchi, S., N. Nakajima, J. SaCK, B. JaCobsen, N. Howard, T. Foley, T. Kaplan, J. Glorieux, H. Reed, F. la Vecchio, $P$. Rochiccioli, J. Dussault: Panel and general discussion diagnosis, treatment and follow-up of children with congenital hypothyroidism. In: BuRROw, G. N., J. H. DussaulT (eds.): Neonatal thyroid screening. Raven Press, New York 1980, p. 277

[16] Landau, H., J. Sack, H. Frucht, Z. Palti, D. HoChNER-CELNIKIER, A. RosenmanN: Amniotic fluid $3,3^{\prime} 5^{\prime}$-triiodothyronine in the detection of congenital hypothyroidism. J. Clin. Endocrinol. Metab. 50 (1980) 799

[17] Lightner, E. S., D. A. Fisher, H. Giles, J. WOOLFENDEN: Intra-amniotic injection of thyroxine $\left(\mathrm{T}_{4}\right)$ to a human fetus. Evidence for conversion of $\mathrm{T}_{4}$ to reverse $\mathrm{T}_{3}$. Am. J. Obstet. Gynecol. 127 (1977) 487

[18] Morley, J. E., R. A. Bashore, A. Reed, H. E. Carlson, J. M. Hershman: Thyrotropin-releasing hormone and thyroid hormones in amniotic fluid. Am. J. Obstet. Gynecol. 134 (1979) 581

[19] Roti, E., G. Robuschi, P. Bandini, R. Emanuele, A. GNUDI: Radioimmunoassay of 3,3'5'triiodothyronine (reverse $\mathrm{T}_{3}$ ) in unextracted serum: concentrations in peripheral vein in normal, altered thyroid economy, after TRH injection and in thyroid vein. J. Nucl. Med. Allied Sci. 23 (1979) 25

[20] Roti, E., F. Malavasi, P. Bandini, G. Robuschi, L. BENASSI, A. GNUDI: 3,3'5'-triiodothyronine concentrations in amniotic fluid at different stages of pregnancy. J. Endocrinol. Invest. 2 (1979) 213

[21] Roti, E.: Pregnancy and PTU. N. Engl. J. Med. 305 (1981) 49 (letter)

[22] Roti, E., S. L. Fang, K. Green, C. H. Emerson, L. E. BRaverman: Human placenta is an active site of thyroxine and 3,3',5-triiodothyronine tyrosil ring deiodination. J. Clin. Endocrinol. Metab. 53 (1981) 498

[23] Roti, E., A. Gnudi, L. E. Braverman, G. Robuschi, R. Emanuele, P. Bandini, L. Benassi, A. Pagliani, C. H. Emerson: Human cord blood concentrations of thyrotropin, thyroglobulin, and iodothyronines after maternal administration of thyrotropin-releasing hormone. J. Clin. Endocrinol. Metab. 53 (1981) 813

[24] Roti, E., S. L. FANG, C. H. EMERson, L. E. BRAVERMAN: Rat placenta is an active site of inner ring deiodination of thyroxine and 3,3',5triiodothyronine. Endocrinology 110 (1982) 34

[25] Roti, E., K. Green, S. L. FANG: Human fetal membranes, a site for thyroxine inner ring deiodi-: nation which may contribute to amniotic fluid re-: verse $\mathrm{T}_{3}$. Endocrinology 190 (1981) T24 (Abstract)

[26] SaCK, J., D. A. Fisher, C. J. Hobel, R. LAM: Thyroxine in human amniotic fluid. J. Pediatr. 87 (1975) 364

[27] Solomon, D. H.: Pregnancy and PTU. N. Engl. J. Med. 304 (1981) 538

[28] Van Herle, A. J., R. T. Young, D. A. Fisher, R. P. ULLER, C. R. BRINKMAN III: Intra-uterine treatment of a hypothyroid fetus. J. Clin. Endocrinol. Metab. 40 (1975) 474

Received June 8, 1984. Revised September 15, 1984. Accepted October 3, 1984.

Correspondence to:

Dr. L. E. Braverman

Division of Endocrinology and Metabolism 55 Lake Avenue North Worcester, Massachusetts 01605, U. S. A. 